\title{
Evaluating the Heavy Metals-Associated Ecological Risks in Soil and Sediments of a Decommissioned Tunisian Mine
}

\author{
Rabiaa Yousfi ${ }^{1 *}$, Zouheir El Ouear ${ }^{2}$, Noura Dahri ${ }^{3}$, \\ Baghdad Ouddane ${ }^{4}$, Hafedh Rigane ${ }^{5}$ \\ ${ }^{1}$ Department of Geology, Faculty of Science, Sfax University, BP 1171, 3000 Sfax, Tunisia \\ ${ }^{2}$ Laboratory Environment Engineering EcotechnologySfax (ENIS) Sfax, Tunisia \\ ${ }^{3}$ GEOMODELE Laboratory, Faculty of Sciences, University of Sfax, BP 1171, 3000 Sfax, Tunisia \\ ${ }^{4}$ Laboratoire Spectrochimie Infrarouge et Raman, Villeneuve d'Ascq, France \\ ${ }^{5}$ Department of Geology, Faculty of Science, Sfax University, BP 1171, 3000 Sfax, Tunisia
}

Received: 17 January 2018

Accepted: 3 March 2018

\begin{abstract}
There is no doubt that mining activities result in a serious threat to the environment. This study dealt with the heavy metals pollution and ecological risk assessment of the former Jebal Ressas mining site on soils and surrounding sediments. Twenty soil samples were gathered from around the mining discharges and agricultural land, and six sediment samples were collected from Wadi Hmma. Then the trace metal elements $\mathrm{Pb}, \mathrm{Zn}, \mathrm{Cd}, \mathrm{As}, \mathrm{Ni}, \mathrm{Cr}$ and $\mathrm{Cu}$ concentrations were determined for these samples. The analyses revealed the presence of the heavy metals ( $\mathrm{Pb}, \mathrm{Zn}, \mathrm{Cd}$ and $\mathrm{As}$ ) in the soil for most of the samples, mainly those close to the mining waste. The $\mathrm{Pb}, \mathrm{Zn}, \mathrm{Cd}$ and As concentrations were remarked to exceed the respective local geo-geochemical backgrounds, indicating an anthropogenic source of pollution. However, the weak presence of $\mathrm{Ni}$ and $\mathrm{Cr}$ with $\mathrm{Fe}$, not exceeding 3, in these soils reflect the natural origin of these elements. The ecological risk potential index study results unveiled that the $\mathrm{Cd}$ content has a significant potential ecological risk.
\end{abstract}

Keywords: heavy metals, mining site, soil and sediment, pollution, ecological risk

\section{Introduction}

Heavy metals persistence in the environment has always been one of the most important research topics. Mining has undeniably contributed to the country's economic development significantly. However, like any

*e-mail: rabiaa88yousfi@gmail.com mining activity it has generated a sharp increase in the levels of toxic heavy metals in the environment [1-3]. Northern Tunisia is an important metallogenic province that used to produce about 2.3 million tons (MT) of lead, 2 MT of zinc and 0.8 MT of fluorine [4].

After the mine's closure, several environmental problems surfaced and mining site construction was abandoned with no planned perspectives. The mere heavy metal pollution was not only degrading the 
quality of the atmosphere, water and food crops, but also threatened human health by way of the trophic chain [5-7]. These have a negative impact on sustainable development concepts. The remains of many heavy metals were found to exceed the environmental standards in the mining areas, causing a potential that could contaminate ecosystems (soil, water). Toxic metals-loaded waste can thus pose a serious threat to rivers and sediments as the fine particles of mine tailings are transported through erosion and leaching $[8,9]$.

Jebel Ressass mining activity has already generated very important quantities of waste ( 2 million tons). Two natural characteristics would aggravate such a threat. These are the semi-arid Mediterranean climate and the carbonated context causing water erosion to play an important role in the transport of the highly-charged solid of $\mathrm{Pb}, \mathrm{Zn}$ and $\mathrm{Cd}$ to neighboring ecosystems [4]; and the great capacity of the calcareous soils of the region to retain high heavy metals concentrations.

This study was meant to tackle four main objectives: firstly it tried to evaluate the metallic trace elements concentrations of $(\mathrm{Pb}, \mathrm{Zn}, \mathrm{Cd}, \mathrm{As}, \mathrm{Ni}, \mathrm{Cr}$ and $\mathrm{Cd})$ in the former Jebel Ressass $\mathrm{Pb}-\mathrm{Zn}$ mine neighboring soils located in northeastern Tunisia. Secondly, it aimed to determine the spatial distribution of these elements in the mine surrounding soils and sediments. Thirdly, it helped identify the sources of pollution using the enrichment factor (EF) and evaluate the contamination level based on the geo-accumulation index $\left(\mathrm{I}_{\mathrm{geo}}\right)$, before finally assessing the associated risk with the heavy metals presence in soils using the ecological risk potential index $\left(\mathrm{E}_{\mathrm{r}}\right)$.

\section{Materials and Methods}

The Study Area and Data Analysis

The Wadi Hmma watershed in northeastern Tunisia covers a drainage basin of $240.2 \mathrm{~km}^{2}$. The altitudes within the basin vary between 15.5 and $738.3 \mathrm{~m}$ (Fig. 1). The Oued Hmma watershed is a Jurassic extrusion that has emerged through the Cretaceous cover containing Triassic levels.

Considered among the best soils in Tunisia, these permeable and fertile soils are of great agricultural value as they are suitable for all types of agriculture. This basin is characterized by a thermo-Mediterranean climate type. The monthly rainfall varies greatly from year to year following the occurrence of short periods

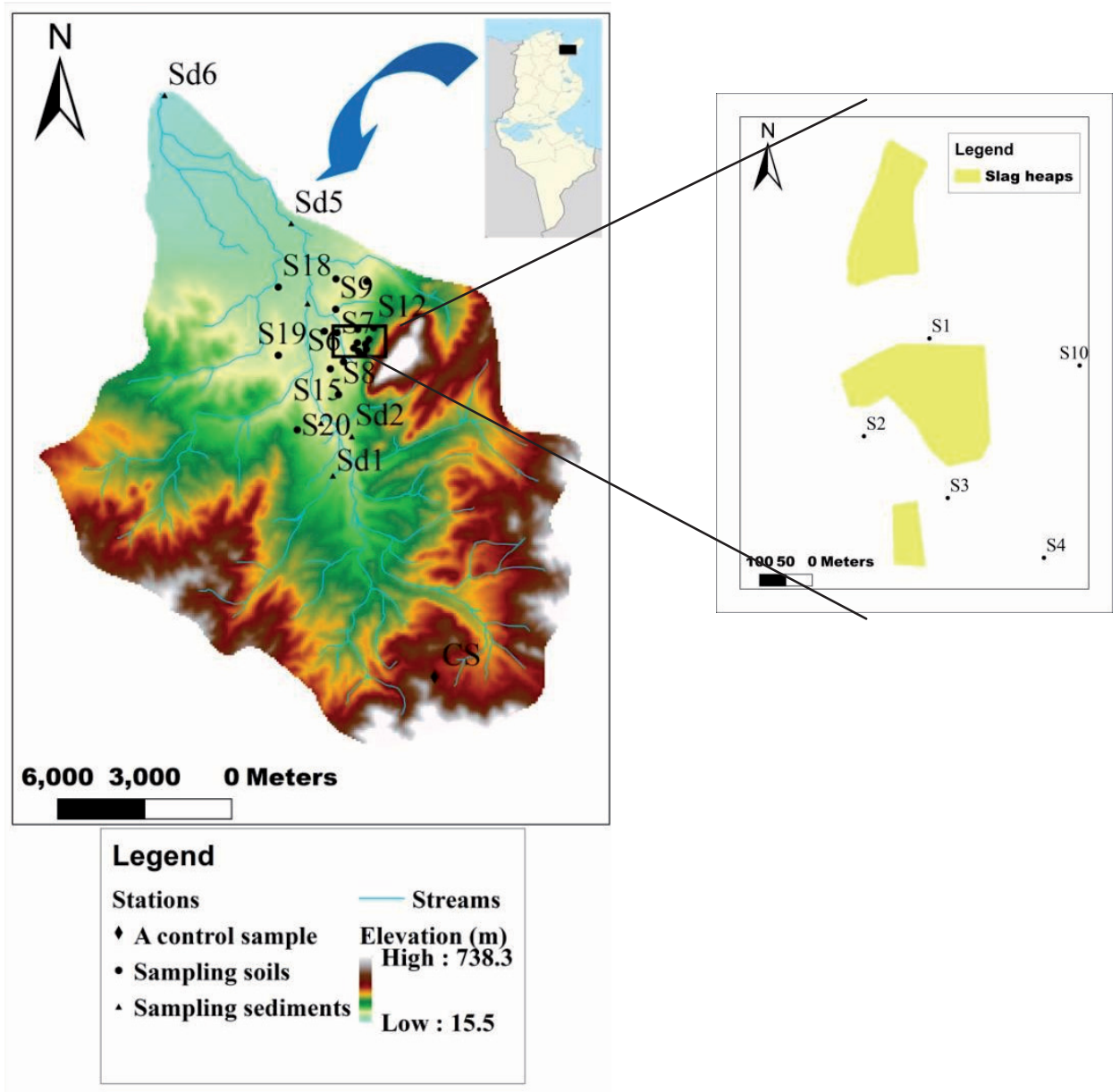

Fig. 1. Geographical location of the study area and sampling points of soil and sediment. 
torrential rains, as characteristic of the climate. The average annual rainfall over 5 years (between 2010 and 2015) is around $531 \mathrm{~mm}$. Measurements at the meteorological station of Tunis Carthage, the nearest meteorological station to the sampling sites, show that the prevailing winds blow from $\mathrm{W}$ to NW. The average annual wind speed is $15.96 \mathrm{~km} / \mathrm{h}$. Unlike the winter, when the $\mathrm{W}$ to NW winds is strong and frequent, the summer winds are mainly from the East and are less strong less common, hot and dry.

The watershed of Oued Hmma is bordered by the $\mathrm{Pb} /$ Zn mining site of Jebel Ressass. This mining site, which was active until 1951, is at the foot of mountains. The mining treatment site is located a few hundred meters to the west, where 3 slag heaps (DI, DII, DIII) consisting of laundry waste-rich in $\mathrm{Pb}, \mathrm{Zn}$ and $\mathrm{Cd}$ are left behind.

After a survey of the study site, 20 surface soil samples $(0-10 \mathrm{~cm})$ were taken: five sediment samples were collected from Oued Hmma stream, one sample at Sbahia Dam and three waste samples from (DI, DII, DIII). The sediment samples were gathered along $16 \mathrm{~km}$ at about $5 \mathrm{~cm}$ deep. A control sample was taken to know the geochemical background of the region. The choice of soil and sediment samples is based on distance from the waste and the different soil types encountered. A soil pit was dug for each sample. The samples were then stored at $4^{\circ} \mathrm{C}$ in polyethylene bags, referenced and transferred to the laboratories of the analytical platform for different analyses.

In addition to the metallic trace elements (MTE), which is at the core of this work, complementary analyses were undertaken to better understand the environmental physicochemical characteristics as a whole. Thus, the soil and sediments characterization was performed as follows: particle size was carried out on soil samples and dry sediments sieved to $2 \mathrm{~mm}$ according to the standardized method (NFX31.107) [10]. Water $\mathrm{pH}$ was measured on $<2 \mathrm{~mm}$ crushed fraction of the soil with a $1 / 2.5 \mathrm{sol} / \mathrm{solution}$ ratio in distilled water according to the NF X 31-117 [11] protocols. $\mathrm{pH}$ was measured in the supernatant after stirring for 1 hour and decantation. Organic carbon was gauged by Anne's method [12] on $<2 \mathrm{~mm}$ fraction. The principle was to oxidize the sample with concentrated sulfuric acid $\mathrm{H}_{2} \mathrm{SO}_{4}$ in the presence of potassium dichromate $\mathrm{K}_{2} \mathrm{Cr}_{2} \mathrm{O}_{7}$. The reduced dichromate amount was determined by colorimetry. The percentage of organic matter was obtained by multiplying the obtained organic carbon content by 1.724 . Calcimetry was carried out using the Bernard calcimeter on $0.25 \mathrm{~g}$ of finely ground soil, the reference being pure calcite. $0.25 \mathrm{~g}$ of raw soil already ground was introduced into an Erlenmeyer flask connected to a volumetric burette. A tube containing 10\% dilute hydrochloric acid was deposited in the flask. Then the tube was tilted, the limestone was attacked and the carbon dioxide was released. $\mathrm{HCl}$ reacts with calcite in the cold, giving $\mathrm{CO}_{2}$ and $\mathrm{CaCl}_{2}$ according to the following expression:

$$
\mathrm{CaCO}_{3}+2 \mathrm{HCl} \quad \mathrm{CaCl}_{2}+\mathrm{CO}_{2}+\mathrm{H}_{2} \mathrm{O}
$$

Measuring the released amount of $\mathrm{CO}_{2}$ during this reaction allows us to calculate the $\mathrm{CaCO}_{3}$ content of the attacked soil sample according to the following formula:

$$
\mathrm{CaCO}_{3}(\%)=\frac{(\mathrm{L} 2-\mathrm{L} 1)_{\text {samplaing }}}{(\mathrm{L} 2-\mathrm{L} 1)_{\text {standard }}} \times 100
$$

...with:

L1: the initial level reading

L2: the final level reading

In order to determine the total metal concentration, some weighed quantities of dried sediments were placed in Teflon tubes and processed with a mixture of concentrated acid at $140^{\circ} \mathrm{C}$ (hydrofluoric acid, hydrochloric acid and nitric acid). Once the sediments were completely dissolved, the solution was diluted with ultrapure Milli-Q water and filtered through a $0.45 \mu \mathrm{m}$ cellulose acetate membrane. Data quality was monitored with reference material using Canadian International Standards (HISS-1, PACS-2) with each series of analyses. The obtained values with this procedure were in good agreement with the certified values and the analytical uncertainties did not exceed 5\%. After mineralization, the total $\mathrm{Pb}, \mathrm{Cd}, \mathrm{Zn}, \mathrm{As}$, $\mathrm{Ni}, \mathrm{Cr}$ and $\mathrm{Cu}$ sample contents were analyzed by inductively coupled atomic emission spectroscopy (ICP-AES).

\section{Sediment and Soil Pollution \\ Assessment Methods}

\section{Enrichment Factor}

Enrichment factor (EF) is a useful tool for determining the heavy metals anthropogenic pollution degree [13]. EF is calculated using the following relationship:

$$
\mathrm{EF}=\frac{\left(C_{X} / C_{A l}\right) \text { sample }}{\left({ }^{C_{X}} / C_{A l}\right) \text { background }}
$$

Since aluminum (Al) is associated with fine solid surfaces, its geochemistry is similar to that of many trace metals and its natural concentration tends to be uniform [13]; it was used as a geochemical standard reference element in this study.

The EF values have been interpreted as suggested by Maanan et al. [13], where $\mathrm{EF}<1$ indicates no enrichment; $<3$ is a minor enrichment; $3-5$ is a moderate enrichment; $5-10$ is a moderately severe enrichment; $10-25$ is a severe enrichment; $25-50$ is a very severe enrichment; and $>50$ is an extremely severe enrichment. 


\section{Geo-Accumulation Index $\left(I_{\text {ged }}\right)$}

The geo-accumulation index $\left(\mathrm{I}_{\mathrm{geo}}\right)$ is defined by the following equation:

$$
I_{\text {geo }}=\log _{2}\left(\frac{C_{n}}{1.5 \times B_{n}}\right)
$$

...where $C_{n}$ is the concentration of the metals considered in the sediment samples and $B_{n}$ is the geochemical background concentration of the metal (n). The factor 1.5 is the correction factor of the background matrix due to lithospheric effects [14]. According to Müller [15], the geoaccumulation index involves seven classes: Class 0 (practically unpolluted): $\mathrm{I}_{\text {geo }} \leq 0$; Class 1 (unpolluted to moderately polluted): $0<\mathrm{I}_{\text {geo }}^{\text {geo }}<1$ Class 2 (moderately polluted): $1<\mathrm{I}_{\text {geo }}<2$; Class 3 (moderately to heavily polluted): $2<\mathrm{I}_{\text {geo }}^{\text {geo }}<3$; Class 4 (highly polluted): $3<\mathrm{I}_{\text {geo }}<4$; Class 5 (highly to extremely polluted): $4<\mathrm{I}_{\text {geo }}<5$; Class 6 (extremely polluted): $5>\mathrm{I}_{\mathrm{geo}}$.

\section{Heavy Metals-Associated Risk}

\section{Ecological Risk Potential Index $\left(E_{r}^{i}\right)$}

To express the potential ecological risk of a given contaminant quantitatively, the risk factor can be defined according to the following equation [16]:

$$
E_{r}^{i}=T_{f}^{i} \times C_{f}^{i}
$$

...where $C_{f}^{i}$ represents the calculated contamination factor, which is obtained by dividing the concentration of each element by its reference value (an unpolluted soil) while $T_{f}^{i}$ corresponds to the toxic response of the heavy metal [17]. According to Hakanson [16], the toxic response factor of the studied heavy metals is: 30 for $\mathrm{Cd}, 10$ for $\mathrm{As}, 5$ for $\mathrm{Pb}$ and $\mathrm{Cu}$ and $\mathrm{Ni}, 2$ for $\mathrm{Cr}$ and 1 for $\mathrm{Zn}$. The ecological risk degree of a metallic element corresponds to the obtained potential ecological risk value $E_{r}^{i}$, where $E_{r}^{i}<40$ indicates low risk; $40<E_{r}^{i} \leq 80$ is moderate risk; $80<E_{r}^{i} \leq 160$ is high ecological risk; $160<E_{r}^{i} \leq 320$ is serious ecological risk; and $E_{r}^{i>320}$ is severe ecological risk [16].

Response of the toxicity of each heavy metal element is different, and the metals whose biological toxicity are strong have a greater proportion in RI, which is shown in the following equation $(\mathrm{Eq})[16]$ :

$$
R I=\sum_{i=1}^{m} E_{r}^{i}
$$

The grade of potential ecological risk of environment, $\mathrm{RI}<150$, is low risk for lake/basin; $150<\mathrm{RI}<300$ is Moderate risk lake/basin; $300<\mathrm{RI}<600$ is considerable risk lake/basin; and $\mathrm{RI}>600$ is Very high risk lake/basin.

\section{Comparison between the Measured Metal Concentrations and the International Threshold Guideline Values}

Several indicators have been developed to evaluate sediment quality (“Sediment quality guidelines, SQGs"). This assessment can be achieved by comparing the obtained heavy metals concentrations to the guideline values [18]. The most commonly used is that proposed by MacDonald et al. [18], namely: TEL (threshold effect level), which is the concentration "threshold" that produces an effect; and PEL (probable effect level), which is the concentration that generates a probable effect.

\section{Statistical Analysis and Spatial Distribution Maps}

The chemo-metric data study was primarily based on the use of such statistical tools as principal component analysis (PCA) and ascending hierarchical classification (AHC). Both of these methods are good tools for identifying pollution sources and providing the best interpretation of results [19]. ArcGIS 10.1 geographic information system software was used to achieve the heavy metals geochemical maps. The inverse distance weighting (IDW) module was applied to interpolate heavy metal concentrations in soil so as to produce the geochemical distribution maps.

\section{Results and Discussion}

\section{Physical Constituents of the Studied Soils and Sediments}

According to Table 1, particle size analysis shows that while a sandy-loam fraction dominates the agricultural soils, soils near the mined deposits are enriched with silt. Quantitatively speaking, it is the soils near the heaps that contain the most dominant proportion of silt $(53.44 \%)$. This can be explained by the wind and water erosion effect, which led to a reduction in fine particles and an increase in coarse ones [20]. El Azhari et al. [21] suggest that the mining discharge soil mobility in the surrounding environment was mainly due to the water erosion effect. The sediment particle size analysis shows that these samples are dominated by the clay-silty fraction.

\section{Soil and Sediment Physicochemical Characterization}

The results relating to $\mathrm{pH}$, total limestone, organic matter and cation exchange capacity (CEC) are displayed in Table 1. The samples' physicochemical study shows that the $\mathrm{pH}$ is basic and varies between 7.37 and 8.50 with an average value of 7.82 , indicating 
Table 1. Descriptive statistics of the physicochemical parameters of soils and sediments from the Oued Hmma watershed.

\begin{tabular}{|c|c|c|c|c|c|c|c|c|}
\hline & & $\mathrm{pH}-\mathrm{eau}$ & $\mathrm{MO}(\%)$ & $\mathrm{CaCo}_{3}(\%)$ & $\mathrm{CEC}(\mathrm{meq} / 10 \mathrm{~g})$ & Clay (\%) & Silt (\%) & Sand (\%) \\
\hline \multirow{4}{*}{ Soil samples (N20) } & Maximum & 8.28 & 7.66 & 45 & 34.02 & 32.44 & 59.72 & 72.53 \\
\cline { 2 - 10 } & Minimum & 7.37 & 0.81 & 11 & 4.34 & 6.75 & 10.22 & 23.32 \\
\cline { 2 - 10 } & Mediane & 7.83 & 2.56 & 32.31 & 10.68 & 16.59 & 31.13 & 49.60 \\
\cline { 2 - 10 } & Average & 7.79 & 2.93 & 29.27 & 15.54 & 17.87 & 34.22 & 47.90 \\
\hline \multirow{4}{*}{$\begin{array}{c}\text { Sediment samples } \\
(6)\end{array}$} & Maximum & 8.5 & 3.45 & 33 & 31 & 63.67 & 37 & 45 \\
\cline { 2 - 10 } & Minimum & 7.5 & 1.2 & 19 & 9 & 35 & 20 & 16.03 \\
\cline { 2 - 10 } & Mediane & 7.94 & 2.15 & 27.50 & 18.75 & 45.00 & 29.66 & 21.50 \\
\cline { 2 - 10 } & Average & 7.90 & 2.24 & 26.27 & 18.72 & 46.70 & 27.77 & 25.54 \\
\hline
\end{tabular}

the soil's alkaline nature. Ma et al. [22] suggest that high $\mathrm{pH}$ values promote adsorption and metals precipitation.

Organic matter ranges between $0.81 \%$ and $7.66 \%$. The richness in this matter is due to the fact that it is agricultural land, and therefore to the presence of dense vegetation that could play a very important role in the retention of certain heavy metals. The CEC is also high, with a minimum value of $4.34 \mathrm{meq} / 10 \mathrm{~g}$, which may reach a maximum of $34.02 \mathrm{meq} / 10 \mathrm{~g}$. This has already been explained by Aprile and Lorandi [23], who stated that the ammonium acetate used in this method promotes the dissolution of carbonates and soluble salts, which leads to the CEC overestimation.

Table 2. Heavy metal concentrations ( $\left.\mathrm{mg} \mathrm{kg}^{-1} \mathrm{DM}\right)$ in soils and sediments of the Oued Hmma watershed.

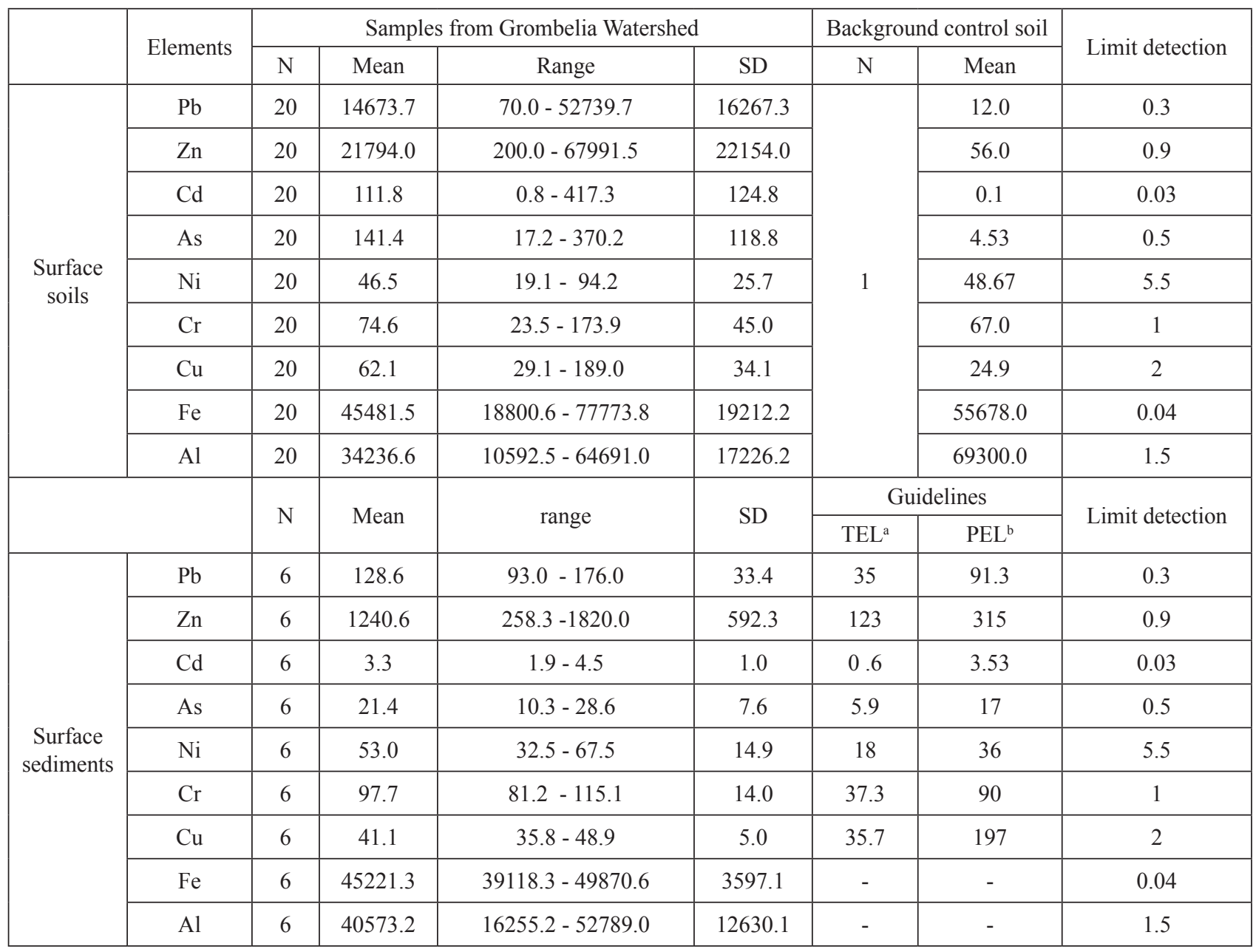

Limit detection $\left(\mu \mathrm{gL}^{-1}\right) \quad \mathrm{N}=$ number of samples $\quad{ }^{\mathrm{a}}=$ TEL: Threshold effect level. $\left(\mathrm{SQG}_{\mathrm{S}}[18]\right.$

$\mathrm{b}=$ PEL: Probable effect level $\left(\mathrm{SQG}_{\mathrm{S}}\right)[18]$ 
Table 3. Comparison of metal concentrations $\left(\mathrm{mg} \mathrm{kg}^{-1}\right)$ in sediments from different sites.

\begin{tabular}{|c|c|c|c|c|c|c|c|c|}
\hline Location & $\mathrm{Zn}$ & $\mathrm{Pb}$ & $\mathrm{Cd}$ & $\mathrm{As}$ & $\mathrm{Ni}$ & $\mathrm{Cr}$ & $\mathrm{Cu}$ & $\mathrm{Reference}$ \\
\hline NE Tunisie (agricol soils) & 67991.5 & 52739.7 & 417.3 & 370.2 & 94.2 & 173.9 & 189.0 & 34 \\
\hline Tailing (DIII) & 74420 & 58540 & 430 & 532.5 & 19.24 & 24 & This study \\
\hline Tailing (DII) & 64349 & 49876.65 & 145 & 234 & 19 & 24.76 & 23 & 47.56 \\
\hline Tailing (DI) & 67678.83 & 49783.32 & 112.65 & 264 & 24.65 & 28.89 & 46 & {$[24]$} \\
\hline Cabezo Rajao (Spain) & 53100 & 19000 & 322 & 587 & - & - & 2255 & {$[25]$} \\
\hline Hunan Province (China) & 18025.31 & 10053.99 & 114.73 & 781.71 & 58.64 & - & 120.52 & {$[25]$} \\
\hline Kombat mine, Namibia & 62 & 164 & - & - & 23 & 46 & 150 & {$[26]$} \\
\hline Zambian Copperbelt & 83 & 42 & - & - & - & - & 8980 & {$[28]$} \\
\hline Southeast Egypt & 92 & 29 & 0.20 & 700 & 260 & 530 & 60 & {$[27]$} \\
\hline
\end{tabular}

To sum up, we can forward these physicochemical conditions sets, the media physical characterization (particle size analysis) as well as the erosion effect favoring the accumulation of metals in the surrounding soils and sediments.

\section{Geochemistry of the Metallic Trace Elements in Soils and Sediments}

The heavy metals total concentration determination was the first step in assessing soil health and ecological risk. For this reason, attempts were made to track the MTE contents in the samples. The heavy metals concentrations in all the soil and sediment samples are shown in Table 2. The obtained values for $\mathrm{Pb}, \mathrm{Zn}, \mathrm{Cd}$ and As are very distinct and spread over very wide ranges. They exceed by far the natural concentrations. $\mathrm{The} \mathrm{Pb}$ contents are of about $52739.7 \mathrm{mg} \mathrm{kg}^{-1}$, while the $\mathrm{Zn}$ values exceed $60000 \mathrm{mg} \mathrm{kg}^{-1}$. The concentrations of $\mathrm{Cd}$ and As recorded in this study show higher levels in most of the samples. For $\mathrm{Ni}$ and $\mathrm{Cr}$ they are present with weak values slightly exceeding natural values. $\mathrm{Cu}$ contents presented low values not exceeding a few tens of mg. $\mathrm{kg}^{-1}$, except for soil sample S3, whereas the copper content reaches $189 \mathrm{mg} \mathrm{kg}^{-1}$. For the sediment, most of the measured metals show that all the sediment samples are rich in MTE. This enrichment is all the more important when going from upstream to downstream. Depending on their abundance in soils and nearby superficial sediments, the analyzed metals were classified in the following order: $\mathrm{Zn}>\mathrm{Pb}>\mathrm{As}>\mathrm{Cd}>\mathrm{Cr}>\mathrm{Cu}>\mathrm{Ni}$

For Al the values are similar or slightly higher than those in the samples closest to the releases. These results show that the samples matrix contains clay minerals. As for Fe, the values are almost of the same order of magnitude.

The Jebel Ressass mining site has high concentrations of metallic trace elements compared to other sites in the world (Table 3). Navarro et al. [24] report high values for the Cabezo Rajao Mine site in SE Spain, with more than $19000 \mathrm{mg} \mathrm{kg}^{-1}$ for $\mathrm{Pb}$,
$53100 \mathrm{mg} \mathrm{kg}^{-1}$ for $\mathrm{Zn}$ and $322 \mathrm{mg} \mathrm{kg}^{-1}$ for Cd. Huyang et al. [25] has suggested that metals concentrations in the $\mathrm{Pb}-\mathrm{Zn}$ mining wastes surrounding soils exceeded the Chinese National (III) standards for environmental and soil quality limits with a maximum of $10053.99 \mathrm{mg} \mathrm{kg}^{-1}, 18025.31 \mathrm{mg} \mathrm{kg}^{-1}, 114.73 \mathrm{mg} \mathrm{kg}^{-1}$ and $781.71 \mathrm{mg} \mathrm{kg}^{-1}$ for $\mathrm{Pb}, \mathrm{Zn}, \mathrm{Cd}$ and $\mathrm{As}$, respectively. However, Mileusnic et al. [26] evoked lower values in soils near a Kombat Mine site in Namibia than those recorded in our study site. The contents found by these authors do not exceed $164 \mathrm{mg} \mathrm{kg}^{-1}$ in $\mathrm{Pb}, 62 \mathrm{mg} \mathrm{kg}^{-1}$ in $\mathrm{Zn}$ and $150 \mathrm{mg} \mathrm{kg}^{-1}$ in $\mathrm{Cu}$. Rashed [27] found levels of up to $29 \mathrm{mg} \mathrm{kg}^{-1}$ for $\mathrm{Pb}, 92 \mathrm{mg} \mathrm{kg}^{-1}$ for $\mathrm{Zn}$ and $60 \mathrm{mg} \mathrm{kg}^{-1}$ for $\mathrm{Cu}$ in the neighborhood of a mining site of Egypt (southeast). In the upper parts of soil horizons in the Zambian Copperbelt, Konečný et al [28] were found to contain high levels of metals with $8980 \mathrm{mg} \mathrm{kg}^{-1}$ for $\mathrm{Cu}, 83 \mathrm{mg} \mathrm{kg}^{-1}$ for $\mathrm{Zn}$ and $42 \mathrm{mg} \mathrm{kg}^{-1}$ for $\mathrm{Pb}$. Therefore, abandoned mine sites mainly represent a source of contamination by heavy metals.

When comparing the heavy metals concentrations presented by most of the previous studies to ours, we can remark that they are much lower, which indicates a high contamination of the studied soils in our work. According to this comparison, the soil and sediment samples are characterized by very high heavy metals concentrations. This proves that the nearby soils of the studied mining site are rich in heavy metals and testify to strong contamination resulting from mining activity. This comparison confirms the importance of the metalliferous contamination in the study area.

\section{Heavy Metals Spatial Distribution in Soils and Sediments}

Heavy metals spatial distribution in soils and sediments was analyzed using GIS. The metal concentrations were interpolated relying on IDW geostatistics. The metals geochemical maps are presented in Fig. 2. The metal concentrations spatial distribution shows two clearly differentiated zones: the "near the 
heaps" grouping of metallic trace elements $\mathrm{Pb}, \mathrm{Zn}, \mathrm{Cd}$ and $\mathrm{As}$, and "agricultural land" containing $\mathrm{Ni}, \mathrm{Cr}$ and $\mathrm{Cu}$. The highest $\mathrm{Pb}, \mathrm{Zn}, \mathrm{Cd}$ and As concentrations were recorded around the waste dumps $\left(52739.7 \mathrm{mg} \mathrm{kg}^{-1}\right.$, $67991.5 \mathrm{mg} \mathrm{kg}^{-1}, 417.3 \mathrm{mg} \mathrm{kg}^{-1}$ and $370.2 \mathrm{mg} \mathrm{kg}^{-1}$ for $\mathrm{Pb}$, $\mathrm{Zn}, \mathrm{Cd}$ and As, respectively). The variation coefficient is
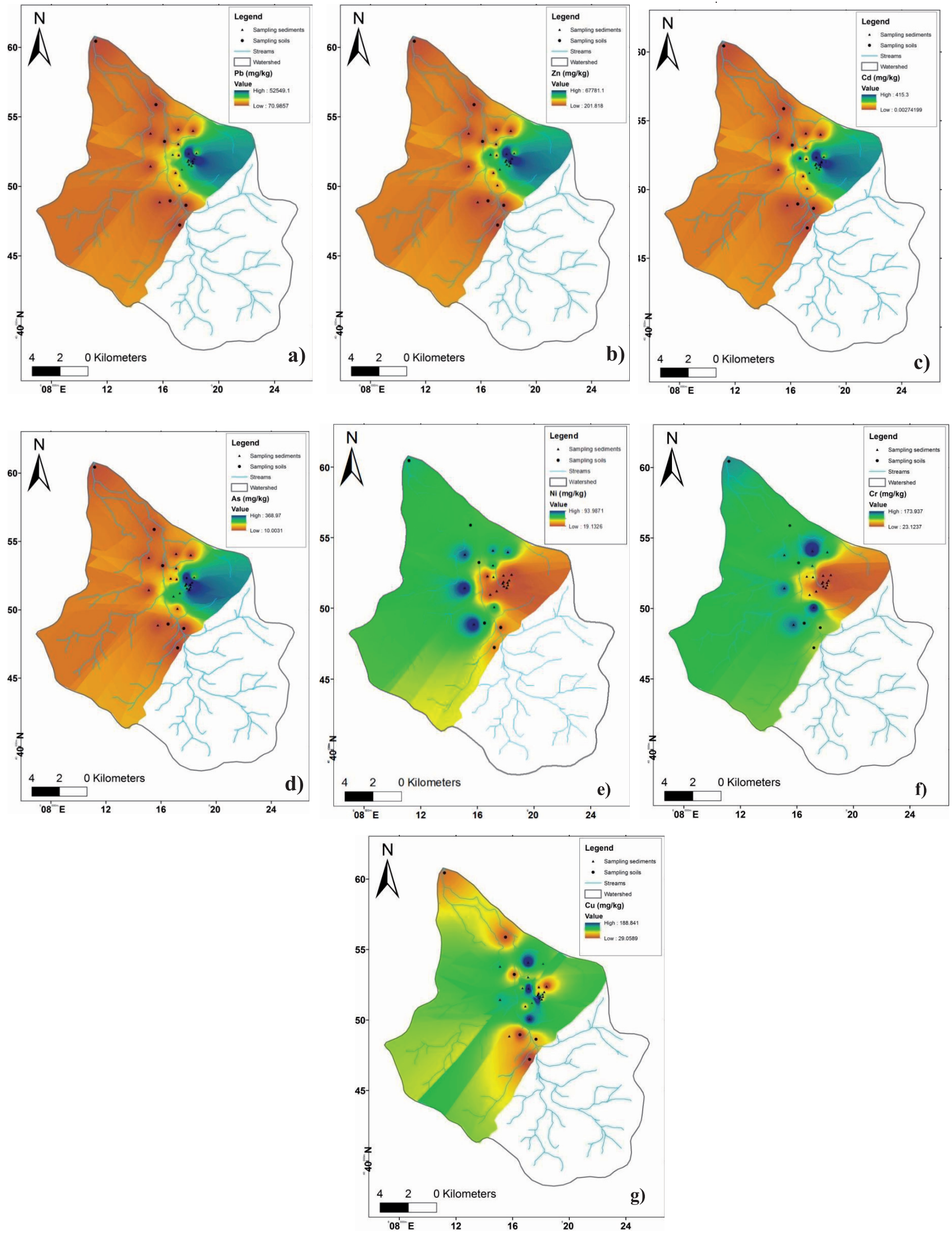

Fig. 2. Soil geochemical maps for: a) $\mathrm{Pb}$, b) $\mathrm{Zn}$, c) $\mathrm{Cd}$, d) $\mathrm{As}$, e) $\mathrm{Ni}$, f) $\mathrm{Cr}$ and g) $\mathrm{Cu}$. 
significant (1.01), (1.10), (1.16) and (0.8) for $\mathrm{Zn}, \mathrm{Pb}, \mathrm{Cd}$ and As, respectively, which might be explained by the $\mathrm{Pb}, \mathrm{Zn}, \mathrm{Cd}$ and As source development [29]. The further away from the waste dump, the lower these metals' concentrations, but they still remain high compared to the guideline values. In addition, the farthest sampling heap stations from the "agricultural land" are characterized by high $\mathrm{Ni}, \mathrm{Cr}$ and $\mathrm{Cu}$ levels. Moreover, Wadi el Hmma sediments have high $\mathrm{Pb}, \mathrm{Zn}, \mathrm{Cd}$, As, $\mathrm{Ni}, \mathrm{Cr}$ and $\mathrm{Cu}$ concentrations downstream of the basin. Such a metal distribution is similar to that found by El Azhari et al. [21] in Morocco.

To refine the results of the aforementioned descriptive study and the effect of the sources as well as the evaluation of the contamination intensity and the eco-toxicological risk of these metals, the use of other chemo-metric approaches based on the calculation of the enrichment factor, the geo-accumulation index, the hierarchical classification and the correspondence factorial analysis remain highly relevant.

\section{Chemo-Metric Approaches}

\section{Enrichment Factor}

\section{The Soils}

The enrichment factor (EF) allows for the assessment of metallic pollution intensity by separating the anthropogenic signal from the natural one. The
EF calculation result (Fig. 3a) reveals that most of the obtained values exceed by far 1 , especially for $\mathrm{Zn}$, $\mathrm{Pb}, \mathrm{Cd}$ and As. These values also show an obvious anthropogenic effect governed by a significant metalliferous contamination of the studied sites. Based on an analysis of the different heavy metals, average EF values were shown to decrease in the following order: $\mathrm{Pb}>\mathrm{Cd}>\mathrm{Zn}>\mathrm{As}>\mathrm{Cu}>\mathrm{Cr}>\mathrm{Ni}$. A further examination of the obtained values indicates that $75 \%$ of the sites (S1-S15) have an extremely severe enrichment with respect to the crust geochemical bottom (Fig. 3a). For the rest of the samples (S16-S20), however, the EF is distributed as follows: for $\mathrm{Zn}, 15 \%$ of the samples (S16-S18) are characterized by a severe enrichment and $10 \%$ (S19-S20) are characterized by a moderate enrichment. For As, 20\% of samples (S16-S19) have moderately severe enrichment and 5\% (S20) have a moderate enrichment. For $\mathrm{Pb}$ and $\mathrm{Cd}, 10 \%$ of the samples (S16-S17) have a very severe enrichment, 5\% (S18) show severe enrichment and 10\% (S19-S20) have a moderately severe enrichment. The spatial distribution of heavy metal enrichment factor showed a progressive increase surrounding the slag heaps.

For $\mathrm{Ni}$ and $\mathrm{Cr}$, the soils are slightly enriched with respect to the crust $(1<\mathrm{FE}<3)$. They probably originated in terrigenous sources. For $\mathrm{Cu}$ (copper), $40 \%$ of the samples (S1-S2-S5-S9-S10-S11-S13-S16) have a moderate enrichment, 25\% (S4-S6-S7-S14-S15) have a moderately severe enrichment and $30 \%$
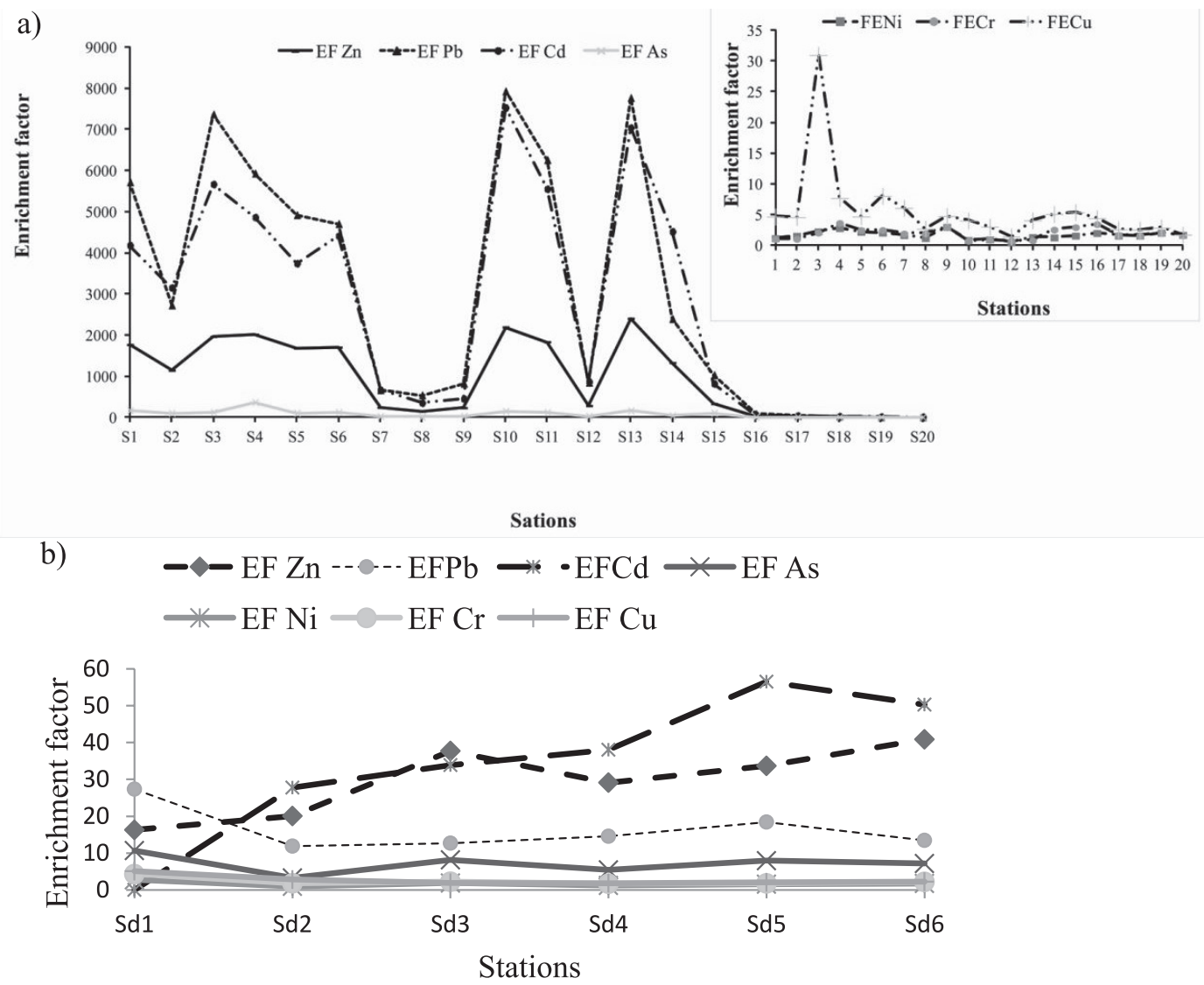

Fig. 3. Lateral variation of enrichment factors for surface horizons a) soil and b) sediment samples. 
(S8 -S12-S17-S18-S19-S20) have a minor enrichment - except for $\mathrm{S} 3(25<\mathrm{FE}<50)$, which shows very severe enrichment. This indicates the presence of a potential anthropogenic source for this element.

The Sediments

As far as the sediments are concerned, the enrichment factor spatial variations (Fig. 3b) for $\mathrm{Zn}$, $\mathrm{Pb}$ and $\mathrm{Cd}$ vary from severe to very severe. For $\mathrm{Zn}$, $33 \%$ of the samples (Sd1-Sd2) have severe enrichment while $67 \%$ (Sd3-Sd4-Sd5-Sd6), located downstream of the basin, have very severe enrichment. For $\mathrm{Pb}$, all the samples exhibit severe enrichment except for Sd1, which has a very severe EF. Enrichment is very severe for $\mathrm{Cd}$ compared to the crust for all the samples. The obtained EF values for As do not exceed $10(5<\mathrm{FE}<10)$ in all the sampling stations, resulting in a moderately severe enrichment for this element. This is attributed to the anthropogenic source of these elements.

Enrichment is minor for $\mathrm{Ni}$ and $\mathrm{Cr}(\mathrm{FE}<3)$ except for $\mathrm{Sd} 1$ for $\mathrm{Cr}$, where it is moderate $(3<\mathrm{FE}<5=4.27)$, indicating a terrigenous source for these two elements. As for $\mathrm{Cu}, 83.33 \%$ of the samples (Sd2-Sd3-Sd4-Sd5Sd6) have minor enrichment and $16.66 \%$ (Sd1) have moderately severe enrichment, revealing a potential anthropogenic source for this element. The order from the highest to the less important of average enrichment factors of the different heavy metals was found to be as follows: $\mathrm{Cd}>\mathrm{Zn}>\mathrm{Pb}>\mathrm{As}>\mathrm{Cu}>\mathrm{Cr}>\mathrm{Ni}$.

The order of the average heavy metals enrichment factors is different between soils and sediments. These results can be attributed to the mobility of $\mathrm{Cd}$ and $\mathrm{Zn}$, and the adsorption of lead by the clay fraction in soils.

The Geo-Accumulation index ( $\left.I_{g e o}\right)$

\section{The Soils}

The $\mathrm{I}_{\text {geo }}$ was used as a criterion to evaluate the contamination intensity of the studied soils and sediments. The $\mathrm{Zn}, \mathrm{Pb}$, Cd and $\mathrm{As} \mathrm{I}$ (Fig. 4a) vary between 1.3 and $9.7 ; 2.5$ and $11.5 ; 2.4$ and $11.4 ; 1.3$ and 5.8 , respectively. For $\mathrm{Zn}, \mathrm{Pb}$ and $\mathrm{Cd}, 75 \%$ of the samples (S1 to S15), which are the closest to the leadzinc discharges, are extremely polluted. $15 \%$ of the $\mathrm{Zn}$ samples (S16-S17-S18) are considered highly polluted and $10 \%$ (S19 and S20) are moderately polluted. Similarly, $15 \%$ of $\mathrm{Pb}$ and $\mathrm{Cd}$ samples (S16-S17-S18) are considered highly to extremely polluted soils and $10 \%$ as moderately to highly polluted (S19-S20). The As contamination intensity varies as follows: close to discharges soils, (S1-S4-S10-S11-S13) are extremely polluted, while other soils (S2-S3-S5-S6-S7-S12S14-S15) are highly polluted. The rest of the soils are moderately polluted. From these results it can be concluded that $\mathrm{Pb}, \mathrm{Cd}, \mathrm{Zn}$ and $\mathrm{As}$ are significantly accumulated in soils.

As for $\mathrm{Ni}$ and $\mathrm{Cr}$, they do not contribute to the contamination of the closest soils to the discharges with

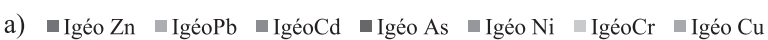

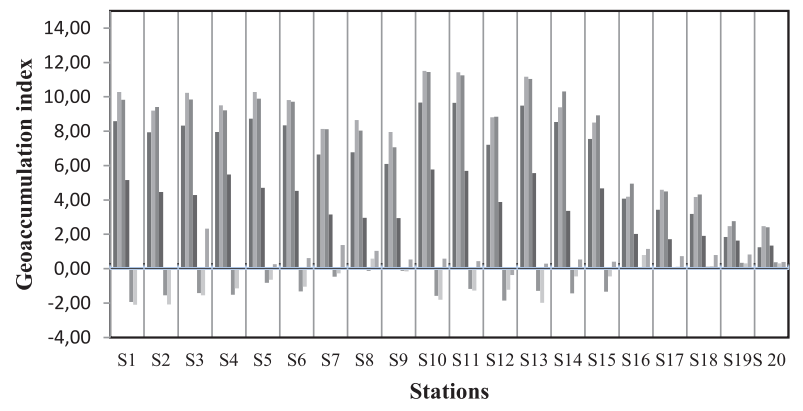

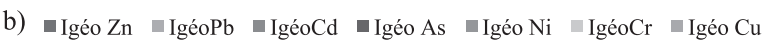

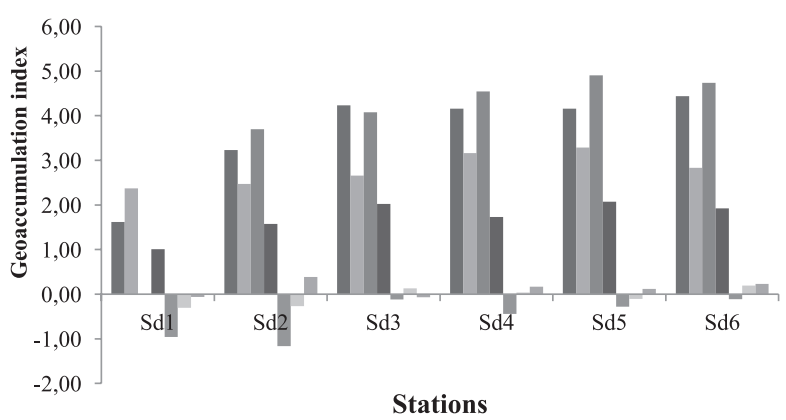

Fig. 4. Geo-accumulation index for surface horizons a) soil and b) sediment samples.

$\left(\mathrm{I}_{\text {geo }}<0\right)$, while soils near agricultural land are unpolluted to moderately polluted with $0<$ Igeo $<1$.

Concerning $\mathrm{Cu}, 10 \%$ of the samples (S4-S12) are unpolluted while $75 \%$ are unpolluted to moderately polluted, except for S3, which is moderately to highly polluted. $15 \%$ of the samples collected from the farmland (S7-S8-S16) are moderately polluted $\left(1<\mathrm{I}_{\text {geo }}<2\right)$. Soil pollution levels are consistent with the spatial distribution of heavy metals total concentrations.

The Sediments

The $I_{\text {geo }}$ results of the sediments (Fig. 4b) show that $\mathrm{Pb}$ contributes to a moderate to strong pollution of $\mathrm{Sd} 1, \mathrm{Sd} 2, \mathrm{Sd} 3$ and $\mathrm{Sd} 6$, and strongly polluted $\mathrm{Sd} 4$ and $\mathrm{Sd} 5$. For $\mathrm{Zn}$ and $\mathrm{Cd}, \mathrm{Sd} 1$ is moderately polluted, $\mathrm{Sd} 2$ is highly polluted and $\mathrm{Sd} 3, \mathrm{Sd} 4, \mathrm{Sd} 5$ and $\mathrm{Sd} 6$ are highly to extremely pollute. All the sampled sediments are moderately polluted by As but none is polluted by $\mathrm{Ni}$ and $\mathrm{Cr}$.

The sediments from $\mathrm{Sd} 2, \mathrm{Sd} 4, \mathrm{Sd} 5$ and $\mathrm{Sd} 6$ are unpolluted to moderately polluted by $\mathrm{Cu}$, while $\mathrm{Sd} 1$ and $\mathrm{Sd} 3$ are totally uncontaminated by this element. Clearly, the sediment contamination levels also follow the spatial distribution of total heavy metal concentration with the highest $\mathrm{I}_{\text {geo }}$ values detected downstream of the basins.

\section{Identifying Pollution Sources}

\section{Correlation Matrix}

The Pearson correlation coefficient for heavy metals at $0.05,0.01$ and 0.001 levels after Student's test 
Table 4. Pearson correlation coefficient for heavy metals in the Oued Hmma watershed soils and sediments.

\begin{tabular}{|c|c|c|c|c|c|c|c|c|c|}
\hline & $\mathrm{Fe}$ & $\mathrm{Zn}$ & $\mathrm{Pb}$ & $\mathrm{Cd}$ & $\mathrm{As}$ & $\mathrm{Ni}$ & $\mathrm{Cr}$ & $\mathrm{Cu}$ & $\mathrm{Al}$ \\
\hline $\mathrm{Fe}$ & 1 & & & & & & & & \\
\hline $\mathrm{Zn}$ & $-0.56^{* *}$ & 1 & & & & & & & \\
\hline $\mathrm{Pb}$ & $-0.5^{* *}$ & $0.99^{* * *}$ & 1 & & & & & & \\
\hline $\mathrm{Cd}$ & $-0.51^{* *}$ & $0.99^{* * *}$ & $0.98^{* * *}$ & 1 & & & & & \\
\hline $\mathrm{As}$ & $-0.61^{* * *}$ & $0.9^{* * *}$ & $0.91^{* * *}$ & $0.87^{* * *}$ & 1 & & & & \\
\hline $\mathrm{Ni}$ & $0.82^{* * *}$ & $-0.63^{* * *}$ & $-0.59^{* * *}$ & $-0.61^{* * *}$ & $-0.69^{* * *}$ & 1 & & & \\
\hline $\mathrm{Cr}$ & $0.78^{* * *}$ & $-0.71^{* * *}$ & $-0.69^{* * *}$ & $-0.68^{* * *}$ & $-0.76^{* * *}$ & $0.86^{* * *}$ & & \\
\hline $\mathrm{Cu}$ & 0.01 & 0.02 & 0.05 & 0.01 & -0.11 & 0.05 & 0.05 & & 1 \\
\hline $\mathrm{Al}$ & $0.78^{* * *}$ & $-0.49^{*}$ & $-0.44^{*}$ & $-0.43^{*}$ & $-0.6^{* * *}$ & $0.76^{* * *}$ & $0.74^{* * *}$ & -0.11 & 1 \\
\hline
\end{tabular}

"Significant correlation at the 0.05 level

${ }^{* *}$ Significant correlation at the 0.01 level

${ }^{* * *}$ Significant correlation at the 0.001 level

$(\mathrm{n}=26)$ were given in Table 4. The results displayed in (Table 4) show a strong correlation between $\mathrm{Pb}, \mathrm{Zn}$, $\mathrm{Cd}$ and $\mathrm{As}$ on the one hand, and between $\mathrm{Ni}, \mathrm{Cr}, \mathrm{Fe}$ and $\mathrm{Al}$ on the other. However, no significant correlation was found between these two groups of elements. In addition, no correlation was found between these two groups and $\mathrm{Cu}$.

\section{Data Processing by PCA}

In order to identify the enrichment source we used PCA [30]. According to this analysis, three main components (F1, F2 and F3) were obtained for the heavy metals, expressing 66.6, 14.2 and $11.5 \%$ of the inertia total variance, respectively. Consequently, the three main control factors impact soil and sediment quality. Only PCs with eigenvalues superior to 1 were considered (Fig. 5).

The projection of the selected metals concentrations on the $1 \times 2$ factorial plane (Fig. 6) shows that the

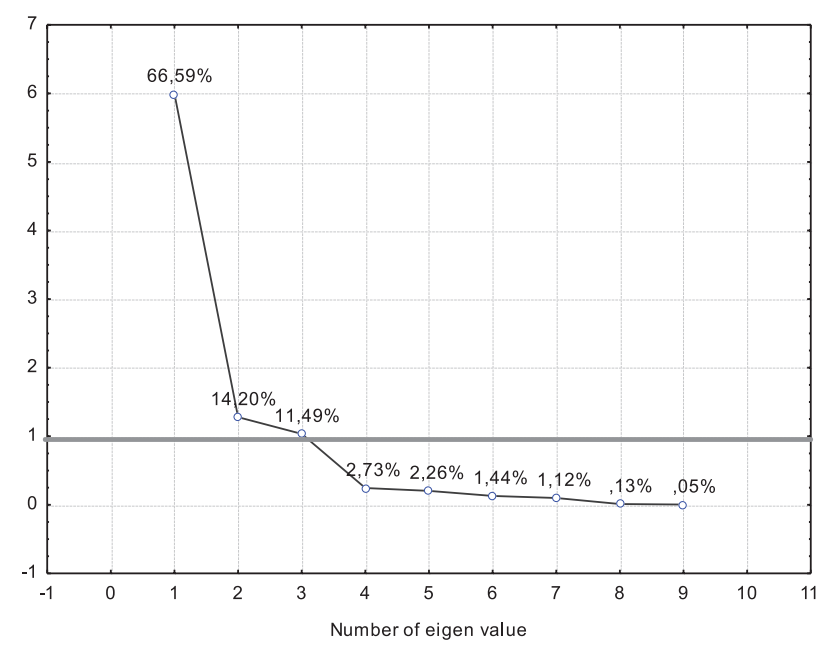

Fig. 5. Scree plot representing the eigenvalues. maximum of inertia is equal to $80.8 \%$. Indeed, the variables are represented on the positive pole of the main inertia axis 1 by $\mathrm{Ni}, \mathrm{Cr}, \mathrm{Fe}$ and $\mathrm{Al}$, and on its negative pole by $\mathrm{Pb}, \mathrm{Zn}, \mathrm{Cd}$ and As. The main axis of inertia 2 is defined by copper on its positive pole. According to this projection, three main groups can be distinguished (Fig. 6). The first group (G1), centered on the Ni, Cr, Al and $\mathrm{Fe}$, and positively correlated with axis 1 . Referring to the study of the enrichment factor (EF), this group is representative of the natural source. A second group (G2) includes $\mathrm{Pb}, \mathrm{Zn}, \mathrm{Cd}$ and $\mathrm{As}$, and is characterized by its great importance on the negative part of axis 1 . This group is anti-correlated with the natural elements $(\mathrm{Ni}$,

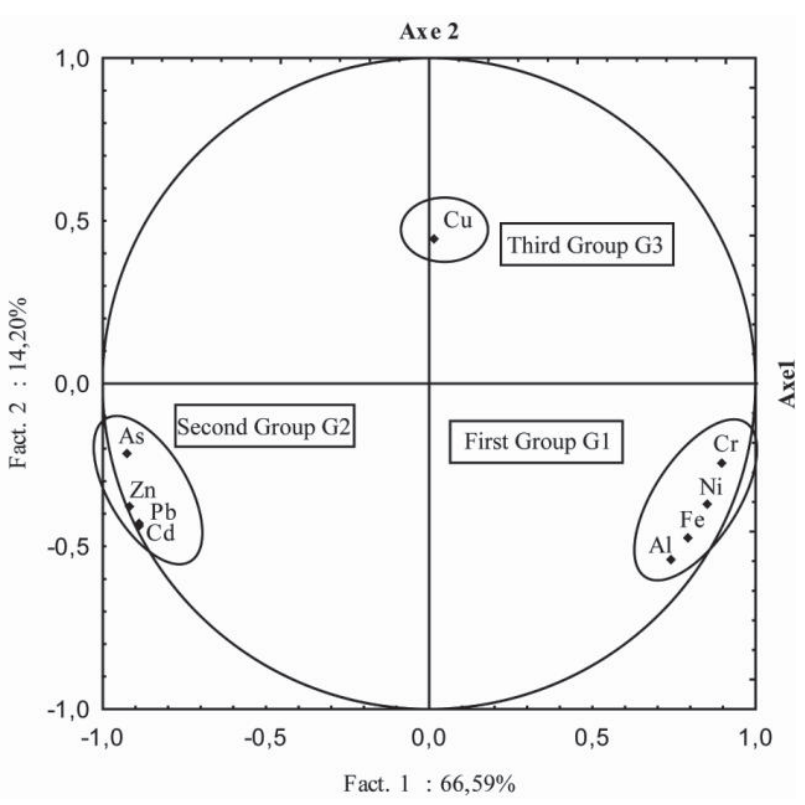

Fig. 6. Projection of the variables on the $1 \times 2$ factorial plane (representing $80.79 \%$ of total variance; meaning threshold $\mathrm{r}=0.373$ for $\mathrm{p}=0.05$ and $\mathrm{n}=26$ ). 


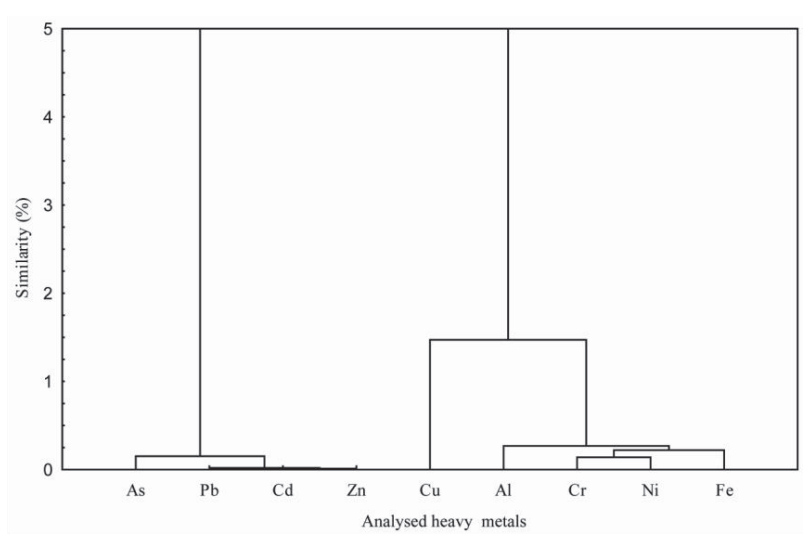

Fig. 7. Dendrograms (distance: Euclidean) showing the clustering of the analyzed metals in soil and sediment samples.

$\mathrm{Cr}, \mathrm{Fe}$ and $\mathrm{Al}$ ). It is also representative of the influence of the anthropogenic component. Lead, zinc, cadmium and arsenic are strongly present in the Jebel Ressass mining deposits with contents that exceed by far the thresholds of these elements' concentrations in the soils (Table 3). This group of elements is therefore necessarily derived from mining discharges. A third group is characterized by a separation of copper from the other elements on the positive part of axis 2 . Referring to the enrichment factor study, this group is representative of the anthropogenic source. The increased accumulation of this element in soils is attributed to the direct long-run use of pesticides and copper-based fertilizers [30-32]. Referring to the spatial distribution, the presence of copper in large quantities in the agricultural land is due to an anthropogenic source basically linked to the use of fertilizers.

\section{Ascending Hierarchical Classification of Data}

The ascending hierarchical classification analysis of the analyzed elements $(\mathrm{Zn}, \mathrm{Pb}, \mathrm{Cd}, \mathrm{As}, \mathrm{Ni}, \mathrm{Cr}, \mathrm{Cu}$, $\mathrm{Fe}, \mathrm{Al}$ ) using the Pearson Ward-test method (Fig. 7) confirms the results obtained from the enrichment factors study and PCA. Indeed, the dendrogram of the 7 elements analyzed highlights 3 classes: the first represented by $\mathrm{Ni}, \mathrm{Cr}, \mathrm{Fe}$ and $\mathrm{Al}$ and revealing the natural components; the second represented by $\mathrm{Zn}, \mathrm{Pb}$, $\mathrm{Cd}$ and As and reflecting the impact of anthropogenic sources - the affinities between $(\mathrm{Zn}, \mathrm{Pb})$ and $\mathrm{Cd}$, on the one hand, and between $\mathrm{As}$ and $(\mathrm{Zn}, \mathrm{Pb}, \mathrm{Cd})$, on the other hand, within this class are to be emphasized; and, finally, the third class is represented by $\mathrm{Cu}$, which unveils an anthropogenic source.

\section{Heavy Metals Potential Ecological Risk in Soils and Surface Sediments}

The potential ecological risk indices of heavy metals in soils and sediments around the mine discharges are displayed in (Fig. 8). For $\mathrm{Zn}, 50 \%$ of the samples (S1-S2-S3-S4-S5-S6-S10- S11-S13-S14) have a severe

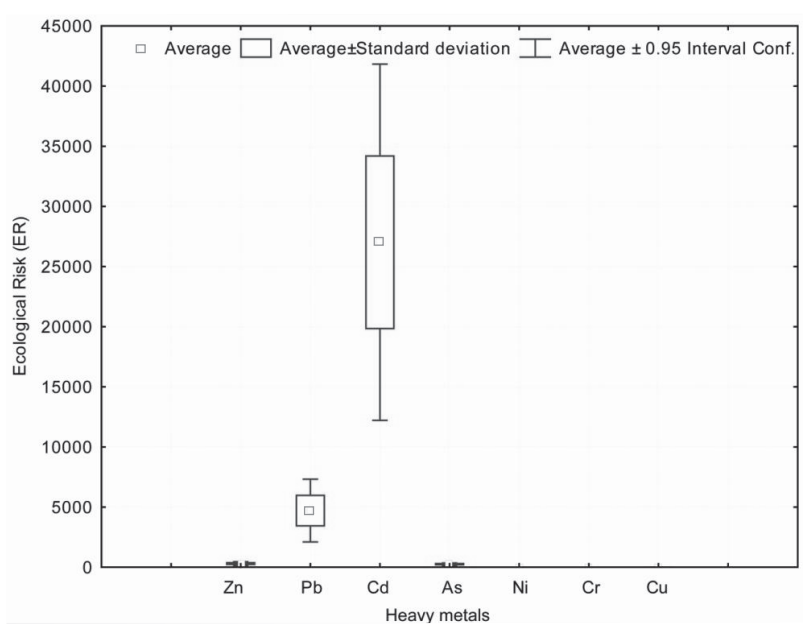

Fig. 8. Box plots for the potential ecological risk $\left(\mathrm{E}_{\mathrm{r}}\right)$ of selected elements in soil and sediment samples.

ecological risk with an average of 697.45. These soils are the closest to the rejects; $10 \%$ of the samples (S8-S12) have a serious ecological risk, 15\% (S7-S9-S15) have a high ecological risk, and 25\% (S16-S17-S18-S19-S20) have a low ecological risk. These are the farthest from the rejects. For $\mathrm{Pb}, 75 \%$ of the samples (S1 to $\mathrm{S} 15$ ) have a severe ecological risk with an average of 8108.84 ; $5 \%$ (S17) have a serious ecological risk, 10\% (S16-S18) have a high ecological risk and $10 \%$ have a low ecological risk. $90 \%$ of the samples (S1 to S18) have a severe Cd-related ecological risk characterized by a very high average of about 37224.59 ; the remaining $10 \%$ (S19-S20) have a serious ecological risk. As far as As is concerned, $45 \%$ of the samples have a severe ecological risk (S1-S2-S4-S5-S6-S10-S11-S13-S15); $10 \%$ (S3-S12) a serious ecological risk, 20\% ( S7-S8S9-S14) a high ecological risk; 20\% (S16-S17-S18-S19) a moderate ecological risk and only S20 has a low ecological risk. On the other half of the deal, the $\mathrm{Ni}, \mathrm{Cr}$ and $\mathrm{Cu}$ trace elements have a low ecological risk in all the sampling stations.

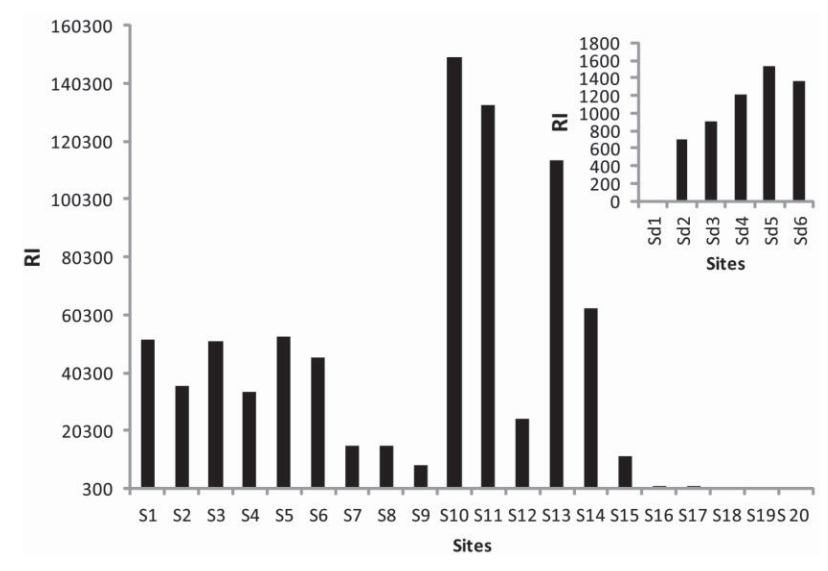

Fig. 9. Total risk toxicity index (RI) of all heavy metals elements $(\mathrm{Pb}, \mathrm{Cd}, \mathrm{Zn}, \mathrm{As}, \mathrm{Cu}, \mathrm{Ni}, \mathrm{Cr})$ in soil and sediment samples. 
The neighboring soils of the mining discharges are characterized by a severe ecological risk. These discharge sites are considered not only as a major potential source of contaminants, but also a serious threat to the surrounding ecological systems [21].

When the sediments are considered, it is worth noting that $\mathrm{Cd}$ is source of severe ecological risk with an average of 988.60, while $\mathrm{Zn}$ presents a low ecological risk with an average of 22.15. For $\mathrm{Pb}$ and $\mathrm{As}$, the ecological risk is moderate except for S1, which shows a low ecological risk. As for the other elements, the ecological risk is rather low.

Although the $\mathrm{Ni}, \mathrm{Cr}$ and $\mathrm{Cu}$ metallic elements have no potential ecological risk alone, the response of the toxicity index is very high risk $(\mathrm{RI}>600)$ at most stations (Fig. 9).

Comparing sediment contamination with the $\mathrm{SQG}_{\mathrm{s}}$ guide values for each trace element, it should be noted that the As, $\mathrm{Cr}$ and $\mathrm{Cu}$ concentrations are $100 \%$ greater than the TEL guideline values, $66.7 \%$ of the $\mathrm{Pb}$ and $\mathrm{Ni}$ concentrations are superior to TEL and 33.3\% of the concentrations are below the PEL guideline. Furthermore for $\mathrm{Zn}, 83.3 \%$ of this element sediment concentration is greater than TEL guideline values and $16.7 \%$ are below the PEL guideline value. For $\mathrm{Cd}$, $80 \%$ of the sediment concentrations are superior to the TEL guideline values and $20 \%$ are below the PEL guideline value. These metals concentrations exceed the TEL and PEL guide values, indicating that these elements are likely to induce dangerous effects on the sediment-dwelling organisms. The increase in the sediment contents of these heavy metals is due to the drainage of the mining wastes sites by the runoff water, which erodes the discharges of mainly the fine part and transports it in rivers during rainy periods. The estimated solid transport at the Sbahia Dam entrance (study basin outfall) reaches $1696 \mathrm{t} / \mathrm{km}^{2} /$ year [33]. Erosion can therefore significantly affect the water resources, which means an urgent need for water and soil management endeavors.

\section{Conclusions}

This study aimed to quantitatively and qualitatively evaluate the impact of Jebal Ressas mining discharge on the soils and sediments of the area. The geochemical analyses show that the studied soils are highly contaminated with such trace metals as $\mathrm{Pb}, \mathrm{Zn}, \mathrm{Cd}$ and $\mathrm{As}$, with contents that may reach up to $52739.7 \mathrm{mgkg}^{-1}$, $67991.5 \mathrm{mgkg}^{-1}, \quad 417.3 \mathrm{mgkg}^{-1}$ and $370.2 \mathrm{mgkg}^{-1}$, respectively. The metals spatial distribution shows an increase in these element concentrations near the mine discharges. While the accumulation of $\mathrm{Ni}$ and $\mathrm{Cr}$ trace elements in agricultural soils is mainly due to a natural source, that of $\mathrm{Cu}$ results from the application of copperbased fertilizers in agriculture.

Several trace metal elements - mainly $\mathrm{Pb}, \mathrm{Zn}$, $\mathrm{Cd}$, and As contaminate the Wadi Hmma sediments with contents that exceed the guideline values and the geochemical background. This accumulation is due to the drainage of the discharges by the runoff water which erodes them (essentially the fine part) and transports it in the rivers during the rainy periods. Different sediment contamination levels were detected downstream of the basins.

The enrichment factor, geo-accumulation index, PCA analysis and the ascending hierarchical classification of the data confirm the origins of these elements and distinguishes between the contamination sources.

Although only the downstream part of the basin in concerned with sediment contamination by metals, such pollution can possibly be extended to water resources. Further studies on these resources are therefore strongly recommended.

\section{Acknowledgments}

This work was funded by the Tunisian Ministry of Higher Education and Scientific Research. The authors would like to thank the reviewers and editor for their valuable comments that helped to improve the manuscript.

\section{Conflict of Interest}

The authors declare no conflict of interest.

\section{References}

1. MACHENDER G., DHAKATE R., RAO S.T.M., RAO B.M., PRASANNA L. Heavy metal contamination in sediments of Balanagar industrial area, Hyderabad, Andhra Pradesh, India. Arab. J. Geosci. 7, 513, 2014.

2. IGWE O., ADEPEHI E.J., IWUANYANWU C., UNA C.O. Risks associated with the mining of $\mathrm{Pb}-\mathrm{Zn}$ minerals in some parts of the Southern Benue trough, Nigeria. Environ. Monit. Assess. 186 (6), 3755, 2014.

3. DAYANI M., MOHAMMADI J. Geostatistical assessment of $\mathrm{Pb}, \mathrm{Zn}$ and $\mathrm{Cd}$ contamination in near-surface soils of the urban mining transitional region of Isfahan. Iran. Pedosphere. 20 (5), 568, 2010.

4. BOUSSEN S., SEBEI A., SOUBRAND-COLIN M., BRIL H., CHAABANI F., ABDELJAOUAD S. Mobilization of lead-zinc rich particles from mine tailings in northern Tunisia by aeolian and run-off processes. Bull. Soc. Géol. Fr. 181, 371, 2010.

5. EL ZRELLI R., RABAOUI L., BEN ALAYA M., DAGHBOUJ N., CASTET S., BESSON P.H., MICHEL S., BEJAOUI N., COURJAULT-RADÉ P. Seawater quality assessment and identification of pollution sources along the central coastal area of Gabes Gulf (SE Tunisia): Evidence of industrial impact and implications for marine environment protection. Mar. Pollut. Bull. 153, 157, 2018.

6. DAHRI N., ATOUI A., EllouZE M., ABIDA H. Assessment of streambed sediment contamination by 
heavy metals: The case of the Gabes Catchment, Southeastern Tunisia. Afr. Earth. Sci. 140, 29, 2018.

7. DONG J., YANG Q.W., SUN L.N., ZENG Q., LIU S.J., PAN J., LIU X.L. Assessing the concentration and potential dietary risk of heavy metals in vegetables at a $\mathrm{Pb} /$ Zn mine site, China. Environ. Earth. Sci, 64, 1317, 2011.

8. CHERNOVA E.N., POTIKHA E.V., NESTERENKO O.E. The Content of Heavy Metals in Bottom Sediments of the Streams of the Sikhote-Alin Biosphere Reserve and the Streams Draining Mines of the Transit Zone of the Reserve. Achi. Life. Sci. 9, 9, 2015.

9. POTIKHA E.V. Hydrobiological Impact Monitoring of Small Streams in Transit Area of Sikhote-Alin Reserve// Sikhote-Alin Biosphere Area: The State of Ecosystems and their Components. Vladivostok. Dalnauka. 258, 2012 [In Russian].

10. CHRISTOPHE C., GIL K., LAURENT S.A., REDON P.O., TURPAULT M.P. Relationship between soil nutritive resources and the growth and mineral nutrition of a beech (Fagus sylvatica) stand along a soil sequence. Catena, 155, 156, 2017.

11. PETARD J. Les méthodes d'analyse: Analyse de sols. Laboratoire commun d'analyse, Tome1, No. 5, ORSTOM, France, 194, 1993.

12. ANNE P. Carbone organique (total) du sol et de l'humus. Ann. Agron. 15, 161, 1945.

13. MAANAN M., SADDIK M., MAANAN M., CHAIBI M., ASSOBHEI O., ZOURARAH B. Environmental and ecological risk assessment of heavy metals in sediments of Nador lagoon, Morocco. Ecol. Ind. 48, 616, 2015.

14. SOLGI E., ESMAILI-SARI A., RIYAHI-BAKHTIARI A., HADIPOUR M. Soil contamination of metals in the three industrial estates, Arak, Iran. Bull Environ Contam Toxicol, 88, 634, 2012.

15. MÜLLER G. Die Schwermetallbelstung der sedimente des Neckars und seiner Nebenflusse: eine Bestandsaufnahme. Chem. Zeitung, 105, 157, 1981.

16. HAKANSON L. Ecological risk index for aquatic pollution control. A sedimentological approach. Water. Res, 14, 975, 1980.

17. MATYS GRYGAR T., POPELKA J. Revisiting geochemical methods of distinguishing natural concentrations and pollution by risk elements in fluvial sediments. J.Geochem. Explor, 170, 39, 2016.

18. MACDONALD D.D., INGERSOLL C.G., BERGER T.A. Development and evaluation of consensus-based sediment quality guidelines for freshwater ecosystems. Arch. Environ. Con. Tox. 39, 20, 2000.

19. YONGMING H., PEIXUAN D., JUNJI C., POSMENTIER E.S. Multivariate analysis of heavy metal contamination in urban dusts of Xi'an, Central China. Sci. Total. Environ. 355 (1-3), 176, 2006.

20. TUO D.F., XU M.X., MA X.X., ZHENG S.Q. Impact of wind-water alternate erosion on the characteristics of sediment particles. Chin. J. Appl. Ecol. 25, 381, 2014.

21. EL AZHARI A., RHOUJJATI A., LAÂRABI EL HACHIMI M., AMBROSI J.P. Pollution and ecological risk assessment of heavy metals in the soil-plant system and the sediment-water column around a former $\mathrm{Pb} / \mathrm{Zn}$ mining area in NE Morocco. Ecotoxicol. Environ. Saf. 144, 464, 2017.

22. MA X. ZUO H., TIAN M., ZHANG L., MENG J., ZHOU X., LIU Y. Assessment of heavy metals contamination in sediments from three adjacent regions of the yellow River using metal chemical fractions and multivariate analysis techniques. Chemosphere. 144, 264, 2015.

23. APRILE F., LORANDI R. Evaluation of Cation Exchange Capacity (CEC) in Tropical Soils Using Four Different Analytical Methods. J. Agri. Sci. 4, 6, 2012.

24. NAVARRO M.C., PEREZ-SIRVENT C., MARTINEZSHANCHEZ M.J., VIDAL J., TOVAR P.J., BECH J. Abandoned mine sites as a source of contamination by heavy metals: A case study in a semi-arid zone. J. Geoche. Exploi. 96 (2-3), 183, 2008.

25. HUANG S.H., LI Q., YANG Y., YUAN C.Y., OUYANG K., YOU P. Risk Assessment of Heavy Metals in Soils of a Lead-Zinc Mining Area in Hunan Province (China). Kem. Ind. 66, 173, 2017.

26. MILEUSNIĆ M., SIYOWI MAPANI B., FRED KAMONA A., RUŽIČIĆ S. Assessment of agricultural soil contamination by potentially toxic metals dispersed from improperly disposed tailings, Kombat mine, Namibia. J. Geochem. Explor. 144, 409, 2014.

27. RASHED M.N. Monitoring of contaminated toxic and heavy metals, from mine tailings through age accumulation, in soil and some wild plants at Southeast Egypt. J. Hazard. Mater. 178, 739, 2010.

28. KONEČNÝ L., ETTLER V., MUNCH KRISTIANSEN S., JOÃO BARROS AMORIM M., KŘÍBEK B., MIHALJEVIČ M., ŠEBEK O., NYAMBE I., JAMES SCOTT-FORDSMAND J. Response of Enchytraeus crypticus worms to high metal levels in tropical soils polluted by copper smelting. J. Geochem. Explor. 144, 427, 2014.

29. WANNAZ E.D., CARRERAS H.A., RODRIGUEZ J.H., PIGNATA M.L. Use of biomonitors for the identification of heavy metals emission sources. Ecol. Ind. 20, 163, 2012.

30. ACOSTA J.A., FAZ A., MARTINEZ M., ZORNOZA R., CARMONA D.M., KABAS S. Multivariate statistical and GIS-based approach to evaluate heavy metals behavior in mine sites for future reclamation. J. Geochem. Explor, 109, 8, 2011.

31. KELEPERTZIS E. Accumulation of heavy metals in agricultural soils of Mediterranean: Insights from Argolida basin, Peloponnese, Greece. Geoderma. 82, 2014.

32. SUN C., LIU J., WANG Y., SUN L., YU H. Multivariate and geostatistical analyses of the spatial distribution and sources of heavy metals in agricultural soil in Dehui, Northeast China. Chemosphere. 92, 517, 2013.

33. BEN OTHMAN D., AYAD I., ABIDA H., LAIGNEL B. Spatial and inter-annual variability of specific sediment yield: case of hillside reservoirs in Central Tunisia. Bull. Eng. Geol. Environ. 1, 2016. 
